\title{
SPECIMENS OF NORTH AMERICAN WATER SHREW FROM DELTA MARSH, MANITOBA
}

\author{
SPENCER G. SEALY, Department of Biological Sciences, University of \\ Manitoba, Winnipeg, MB R3T2N2
}

The range of the North American water shrew (Sorex palustris) in Manitoba extends from the northern tree-line south to include outliers of the boreal forest in the aspen-oak transition zone. ${ }^{1,2,3}$ Populations of this shrew persist on the Porcupine, Duck, and Riding mountains, and in the Carberry Sandhills. . $^{4,5,6,7}$ North American water shrew also has been recorded at Delta Marsh, based on one specimen collected in the 1940s. I report three additional specimens found dead at Delta Marsh.

\section{Previous specimen of water shrew from Delta Marsh}

One specimen of North American water shrew (hereafter, water shrew), collected along the northern edge of Delta Marsh $\left(5011^{\prime} \mathrm{N}, 98^{\circ} 19^{\prime} \mathrm{W}\right)$, Manitoba, was reported in the literature. ${ }^{8,9}$ Tamsitt noted (p. 73) that J. Dewey Soper "obtained a young adult male from the shore of the Delta Research Station pond"8, which had been collected by William $\mathrm{H}$. Elder. ${ }^{9}$

The vertebrate collection of the Delta Waterfowl and Wetlands Research Station was transferred several years ago to The Manitoba Museum (TMM, formerly Manitoba Museum of Man and Nature) in Winnipeg, but no specimen of the water shrew was among those transferred, and none was entered into the catalogue ( $\mathrm{J}$. Klapecki, pers. comm.). Soper collected mammals in Manitoba intermittently from 1927 to 1948 and deposited them in the collections of the Canadian
Museum of Nature, Ottawa, Ontario, and Department of Biological Sciences (then Department of Zoology) at the University of Alberta, Edmonton. ${ }^{10}$ In January 2002, I examined a specimen of a water shrew taken at Delta Marsh that was catalogued at the University of Alberta, Museum of Zoology (UAMZ 1407). Soper's personal label attached to the specimen included his personal collection number, \#4580, and confirmed the shrew as a young male. Another label indicated the original collector, W.H. Elder. The specimen was taken on 7 August 1941, not 1947, as Hochbaum had reported. ${ }^{9}$ Only the skin was located but measurements were taken before the specimen was prepared: total length $=142 \mathrm{~mm}$; tail vertebrae $=61 \mathrm{~mm}$; and hind foot $=$ $19 \mathrm{~mm}$. Soper either received the specimen directly from Elder or it was among other specimens transferred from the Delta Waterfowl Station to the University of Alberta. Moore included the water shrew, based on Elder's specimen, in a list of mammals from Delta Marsh that was prepared for the annual meeting of the American Society of Mammalogists ${ }^{11}$, held in Winnipeg in 1965. No water shrews were collected in various habitats in and around Delta Marsh during intensive trapping by Tamsitt in $1958^{8}$ or by Robert E. Wrigley and co-workers during the 1970s. ${ }^{2}$

\section{Recent specimens of water shrew from Delta Marsh}

Students and I studied the behavioural ecology of songbirds, and parasitism by the Brown-headed Cowbird (Molothrus 
ater), between 1974 and 2010, mostly along the narrow forested dune ridge that separates Delta Marsh and Lake Manitoba $\left(50^{\circ} 11^{\prime} \mathrm{N}, 98^{\circ} 19^{\prime} \mathrm{W}\right)^{12}$, but also at various sites in and around Delta Marsh. During these years, it was not unusual to find dead shrews on the road that extended the length of the forested ridge along which we worked (Fig. 1). Of the shrews identified, masked shrew (Sorex cinereus), arctic shrew (S. arcticus), and northern short-tailed shrew (Blarina brevicauda) were most frequently recorded. These shrews had been killed by a mammalian predator, as evidenced by tooth marks in most cases, and apparently were discarded (Sealy, unpublished data). In 2001, two water shrews (Fig. 2) were among the shrews found dead that year on the ridge road at Delta Marsh, both killed by mammals, and also apparently discarded, in both cases less than 2 $\mathrm{m}$ from the moist edge of the marsh. I weighed, measured, and prepared both shrews as specimens (skin and skull) and deposited them in the mammal collection of The Manitoba Museum.

The first specimen, a lactating female (TMM 24040), was found by Rebecca R.M. Stewart on 6 June 2001. It weighed $19.1 \mathrm{~g}$, was moderately fat, and bore six placental scars (2 scars on the left horn and 4 on the right). This number is within the range of five to eight embryos normally produced by water shrews. ${ }^{13}$ Two puncture wounds, presumably tooth marks, were visible at the base of the skull, and the rib cage

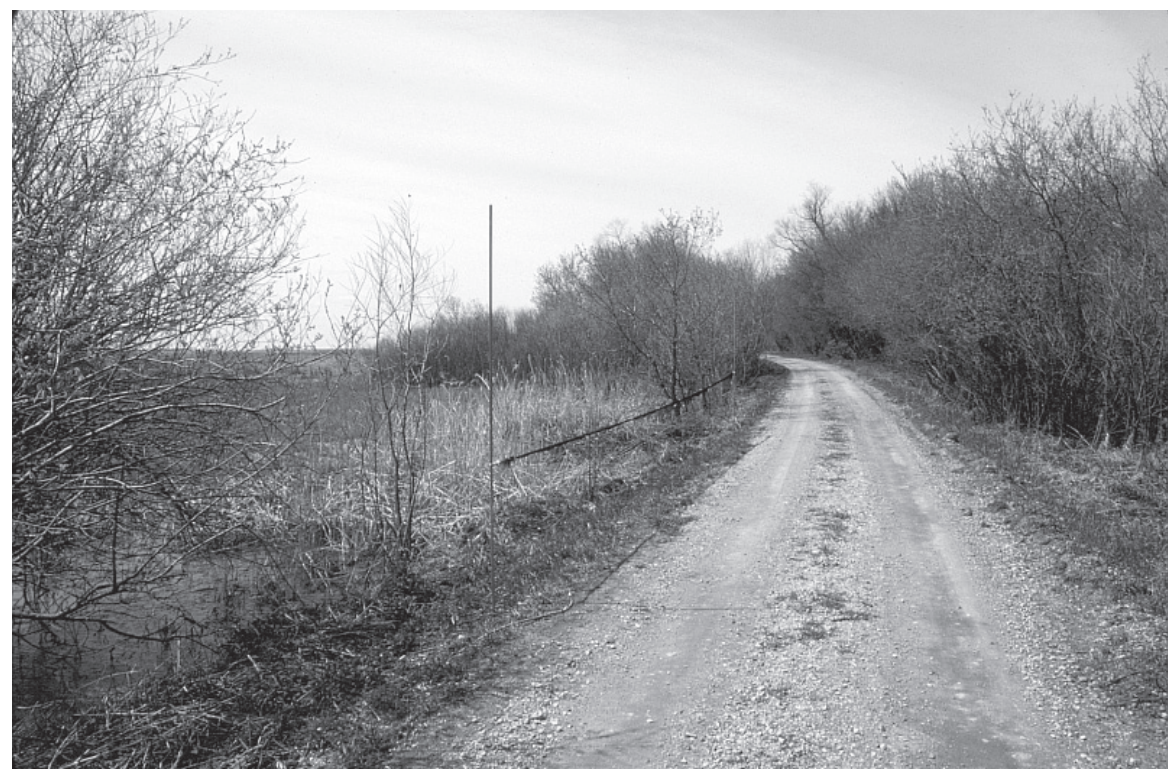

Figure 1. Road along south edge of the dune-ridge forest, Delta Marsh, similar to that on which the dead American water shrews were found. To the right of the road, the dune ridge supports predominantly Manitoba maple (Acer negundo), green ash (Fraxinus pennsylvanica), and peach-leaved willow (Salix amygdaloides). To the left of the road, along the edge of the marsh, are predominantly sedges (Carex spp.) and sandbar willow (S. interior). 


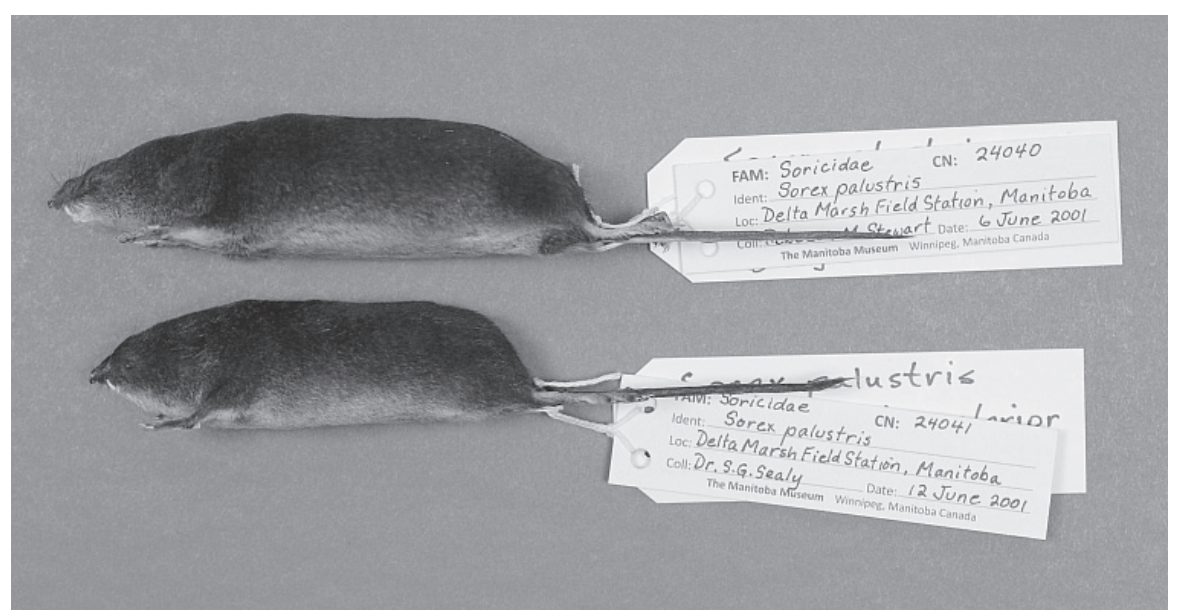

Figure 2. North American water shrews salvaged at Delta Marsh, Manitoba: top, adult female (TMM 24040); bottom, juvenile female (TMM 24041).

was punctured. The second specimen was salvaged on the road at the edge of the marsh about $1 \mathrm{~km}$ west of the first, on 12 June 2001. This specimen was a juvenile female (TMM 24041) that weighed $8.4 \mathrm{~g}$ and exhibited little fat. Its cranium had been crushed, apparently by the bite of a mammal. The mass of these specimens fell within the ranges for breeding female and juvenile water shrews, respectively. ${ }^{13}$

On 19 June 2005, I found a third water shrew at Delta Marsh on a lawn near a cottage in the middle of the dune-ridge forest, about $30 \mathrm{~m}$ from the nearest water. Its tail was curiously knotted with the tails of two deer mice (Peromyscus maniculatus). The specimens, which had been stored in a freezer, were destroyed during a power outage caused by a fire in late March 2009. Only the mammals' identities were determined and I had not examined the knots closely enough to identify a substance that might have "glued" the tails together, or to determine whether this was, albeit doubtfully, a hoax. Knotted tails have been reported previously, in rodents ${ }^{14,15}$, but apparently not in shrews. An instance of knotted tails in four young eastern fox squirrels (Sciurus niger) was reported in Weyburn, Saskatchewan, in 2003. ${ }^{15}$ Hoium speculated that the knots resulted from close contact among the squirrels in their nest: the tails may have become covered with sap or loose stools that dried, sticking them together, and later became entangled. ${ }^{15}$

The circumstance that brought a water shrew and two deer mice of unknown age together, closely enough for their tail's to become entangled, is not known. It seems unlikely, however, that these individuals ended up in a nest together, as water shrews and deer mice kept in captivity avoid each other. ${ }^{16}$ We will never know for sure how their tails become knotted.

\section{Acknowledgements}

Jack Dubois and Janis Klapecki permitted me to examine and borrow specimens of water shrews under their care in The Manitoba Museum. More 
recently, Klapecki catalogued two of the specimens reported in this paper and facilitated photography. Michel Gosselin searched the collection of the Canadian Museum of Nature for specimens of water shrews from Delta Marsh and Wayne E. Roberts allowed me to examine specimens in the collection of the Department of Biology at the University of Alberta. I thank Rebecca R.M. Stewart for salvaging one of the shrew specimens and an anonymous reviewer for comments on the manuscript. Our long-term research on the behavioural ecology of birds at Delta Marsh was funded chiefly by the Natural Sciences and Engineering Research Council of Canada.

1. Banfield AWF (1974) The Mammals of Canada. National Museums of Canada, University of Toronto Press, Toronto, ON.

2. Wrigley RE, Dubois JE, Copland HWR (1979) Habitat, abundance, and distribution of six species of shrews in Manitoba. Journal of Mammalogy 60:505-520.

3. Sealy SG (2002) Discovery of a "lost" specimen of the American water shrew from Churchill, MB. Blue Jay 60:113-115.

4. Seton ET (1909) Life histories of northern animals - an account of the mammals of Manitoba. Charles Scribner's Sons, New York, NY.

5. Criddle S (1929) An annotated list of the mammals of Aweme, Manitoba. Canadian Field-Naturalist 43:155-159.

6. Dubois JE (1973) Trip to Riding Mountain. Manitoba Nature 14:26-29.
7. Wrigley RE (1974) Mammals of the Sandhills of southwestern Manitoba. Canadian Field-Naturalist 88:21-39.

8. Tamsitt JR (1962) Mammals of the Delta Marsh region of Lake Manitoba, Canada. Canadian Field-Naturalist 76:71-78.

9. Hochbaum PW (1971) The Delta Marsh. Manitoba Department of Mines, Resources and Environmental Management, Conservation Extension Branch, Winnipeg, MB.

10. Soper JD (1961) The mammals of Manitoba. Canadian Field-Naturalist 75:171-219.

11. Moore DD (1965) Mammals of the Delta Marshes. Wildlife Branch, Manitoba Department of Natural Resources, Winnipeg, MB.

12. MacKenzie DI (1982) The forested dune-ridge, Delta Marsh, Manitoba: overstory vegetation and soil patterns. Canadian Field-Naturalist 96:61-68.

13. Conaway CH (1952) Life history of the water shrew (Sorex palustris navigator). American Midland Naturalist 48:219-248.

14. Hendrickson R (1999) More cunning than man: a social history of rats and men. Dorset Press, New York, NY.

15. Hoium G (2004) Squirrel tails tied in knots. Blue Jay 62:137-139.

16. Sorenson MW (1962) Some aspects of water shrew behavior. American Midland Naturalist 68:445-462. 